\title{
Discussion of Innovation and Entrepreneurship Education
}

\author{
Xue-Bin JIA \\ Department of Computer, Wuhan polytechnic, Wuhan 430074, China \\ 1139061894@qq.com
}

Keywords: college students; innovation and entrepreneurship; content system; the curriculum.

\begin{abstract}
Innovation and entrepreneurship development of universities, is a major strategic measure to cultivate talents with innovative spirit and strong practical ability for national construction, which is an important subject of education teaching reform in colleges and universities. We attach great importance to the main problems existing in innovation and entrepreneurship education. We attach great importance to the main problems existing in innovation and entrepreneurship education. Bold exploration to construct innovative entrepreneurship education system and curriculum content, strengthening practice teaching innovation entrepreneurship education, strengthening the construction of innovation and entrepreneurship education teachers, and perfect the safeguard measures, is the key to improve the quality of cultivating innovative talents.
\end{abstract}

\section{Introduction}

Innovation entrepreneurship education is to cultivate entrepreneurial basic quality and create a type of personality as the goal, not only to foster students consciousness of entrepreneurship, entrepreneurship, innovation, entrepreneurship education, but to face to the whole society, for which intends to entrepreneurship, business has been, successful entrepreneurial business groups, in stages hierarchical education of creative thinking training and entrepreneurship ability of exercise. Innovation and entrepreneurship education is essentially a practical education.

\section{The importance of innovation and entrepreneurship education}

Entrepreneurial innovation in 1991, the Tokyo international conference on education from the broad sense of "entrepreneurial innovation education" is defined as: to cultivate the most groundbreaking personality, including initiative, risk-taking, entrepreneurship, independent working ability and the cultivation of technical, social and management skills.

Ministry of education "about vigorously promote the innovation in institutions of higher learning entrepreneurship education and college students' self-employment work opinion" pointed out: "entrepreneurship education in colleges and universities to carry out the innovation, and actively encourage college students self-employment, is deep study practice scientific development concept, education system in the service of major strategic measures for the construction of innovation-oriented country; It is an important way to deepen the teaching reform of education and cultivate students' innovative spirit and practical ability. It is an important measure to carry out entrepreneurship to promote employment and promote the full employment of college graduates.

Government attaches great importance to the development of the creative education activities in college and universities, adhere to the principle of strong base, build the platform, reboot, create good innovation environment of entrepreneurship education, optimize the environment of innovative entrepreneurial system and service, build the campus culture encourages innovation entrepreneurship environment, strive to build a full cover, hierarchical, a system of innovation in colleges and universities entrepreneurship education system. 


\section{The necessity of innovation and entrepreneurship education}

The cultivation of college students' innovation and entrepreneurship ability is a very important content of education, which is of great significance for college students to further study and future employment. In addition, from the perspective of college students' employment and national development, education innovation and entrepreneurship is very necessary.

\subsection{The need for national development strategy}

It is an important problem for innovation and entrepreneurship education in colleges and universities to establish a curriculum system suitable for the cultivation of innovative entrepreneurial talents. "Improving the capacity of independent innovation, building an innovative country" and "promoting employment through entrepreneurship" is the grand strategy of national development. In order to respond to national innovation and entrepreneurship education, colleges and universities must carry out double-innovation reform on the existing curriculum system. The university fosters innovation and entrepreneurship ability of university students, and carries out innovation and entrepreneurship education, which is a major strategic measure to further study and practice the scientific development view of education system and serve the construction of innovation-oriented country. It is an important way to deepen the teaching reform of education, cultivate students' innovative spirit and practice ability, and improve students' self-development ability. It is an important measure to carry out entrepreneurship to promote employment and promote the full employment of college graduates. As a new concept of education, education innovation and entrepreneurship has formed a broad consensus in education in China's universities, and has become a new direction of China's higher education talent training model.

\subsection{The need for student employment}

In today's world, and the rapid development of IT technology, Internet +, cloud computing, big data, Internet and other new things, and continuously go deep into the life of dribs and drabs and all walks of life. In this context, on the one hand, the enterprise demand for the quality of college students is the fundamental change, enterprises need to students with strong innovation ability, the enterprise hope graduates to adapt to the rapid development in today's IT technology; On the other hand, enterprises want to reduce their own burden and hope that the school will undertake the task of cultivating innovative and entrepreneurial graduates. Therefore, the school is obliged to strengthen students' innovation and entrepreneurship ability for the high quality employment of students.

\section{Innovation and entrepreneurship education content system}

Awareness: the enlightenment of students' innovative consciousness and the entrepreneurial spirit, make students understand the quality requirement of the innovative talents, understand the concept, elements and characteristics of entrepreneurship, make the students master the basic knowledge required to conduct business activities.

Ability to improve: analyze and cultivate students' critical thinking, insight, decision-making ability, organization and coordination ability and leadership, etc., so as to make students have the necessary entrepreneurial ability.

Environmental cognition: to guide students to understand the current enterprise and industry environment, understand the entrepreneurial opportunities, grasp the risks of entrepreneurship, master the process of business model development, design strategies and techniques, etc.

Practice simulation: through business plan writing, simulated practice activities, students are encouraged to experience all aspects of entrepreneurship preparation, including the pioneering market assessment, financing, start a business process and risk management, etc. 


\section{Innovation and entrepreneurship education curriculum setting}

The education concept of university student innovation and entrepreneurship is to be transformed into education practice, and it needs to rely on the effective curriculum carrier. The curriculum system is the key to realize innovation and entrepreneurship education. Innovation entrepreneurship education curriculum system mainly consists of the following three levels: the first level, facing all students, aims to cultivate students' innovative entrepreneurial awareness, inspire students' innovative entrepreneurial drive the popularity of course; The second level is aimed at students with strong innovation, willingness and potential to improve their basic knowledge, skills and skills. The third level, aims to cultivate students' innovative undertaking all kinds of practical skills practice activity curriculum, to guide, with projects, activities for teaching and practice, the combination of a targeted to strengthen the guidance of the entrepreneurial process for students.

\section{Conclusion}

Form a hierarchical, targeted education system. Colleges and universities should be good at innovation entrepreneurship education discipline advantage can be converted to advantage, infiltration in the professional education teaching innovation of entrepreneurship education idea and content, build ।"ace all, combined with professional, progressive phase as।" innovation entrepreneurship education system. In view of the lower grade students, can carry out general education innovative undertaking and open academic frontiers, such as entrepreneurial foundation general class required and elective courses, pay attention to innovative entrepreneurial basic quality training; In view of the students with entrepreneurial interests, can carry out innovative entrepreneurial heuristic education, innovative entrepreneurial practice training, guide students to take an active part in all kinds of innovative entrepreneurship competition, improve the practice ability; Hope to have a strong entrepreneurial intention into practice, students can open a class, pay attention to the business of actual combat ability, management ability, marketing ability, the key support innovative undertaking in the field of strategic emerging industries.

To strengthen the construction of innovation and entrepreneurship education teachers, teacher is the key to foster innovation entrepreneurship education, teachers' ideological level, knowledge level, teaching and scientific research ability will directly influence on the students, to some extent can say teachers ability level determines the teaching effect, only the teachers have the ability to creative thinking and the corresponding teaching, to cultivate students with creative thinking and ability, good teachers will have subtle influence on students. To strengthen the construction of education faculty of innovation and entrepreneurship, one is to build a team of teachers responsible for innovation and entrepreneurship education. Special training should be carried out to make it not only have advanced ideas, but also have good professional quality and play an active leading role in innovation and entrepreneurship reform practice. The second is to train all teachers. Innovation and entrepreneurship education will finally be implemented in various professional teaching practice, to strengthen the innovation and entrepreneurship education awareness of all teachers and improve the teaching skills of education innovation. Third, we will set up a high-quality innovation and entrepreneurship education teachers team. Pay attention to play to the role of the social professional and technical personnel, can the society related experts, technical authority hired as part-time teachers, held seminar, lead the students to carry out the topic research, teach business knowledge and skills.

To strengthen the guarantee construction innovation and entrepreneurship education is a major reform of education teaching, which requires the support, cooperation and joint efforts of all aspects of the school. To ensure innovation entrepreneurship education spending, especially a fledgling stage, whether it is course construction, base construction, laboratory construction, construction of teachers team, or project competition, all need certain financial support. To create conditions, support the premises, venues, equipment and other aspects. To strengthen the work of leadership, for the sake of universities should be combined with our actual teaching reform pilot first, on the basis of obtained certain experience to gradually away, pilot stage to select effective cadres and teachers have rich experience and love the job. In a word, we should strengthen leadership, overcome difficulties, create 
conditions and persevere, only in this way can we truly make innovation and entrepreneurship education fall into place.

\section{References}

[1] The ministry of education: opinions on the promotion of innovation and entrepreneurship in higher schools, education and college students' own entrepreneurial work.

[2] ZHENG Zhongqi,ZHOU Zhiqiang.The problems and countermeasures of the education system for college students' innovation and entrepreneurship", "innovation and entrepreneurship education, 2014.

[3] LI Guohu.The research on the current situation of university college students' innovation and entrepreneurship education,education of contemporary profession, 11th issue of 2013.

[4] YANG Bo. The construction of education system of innovation and entrepreneurship in Open University, journal of hunan radio and TV university, 3rd issue, 2014.

[5] JIANG Caixia.The research on innovation and entrepreneurship ability of college students based on the practical training, human resources management, no. 9, 2011.

[6] The state council of the CPC central committee:The national medium and long term education reform and development planning outline (2010-2020), Beijing: people's press 2010 edition, page 29.

[7] WANG Jinsong.The innovation and entrepreneurship education is an important task for universities. People.cn - People's Daily. July 10, 2017. 